\title{
EFEKTIVITAS KOMUNIKASI PEMBELAJARAN DARING TERHADAP PEMAHAMAN MATERI KULIAH MAHASISWA UIN SUNAN AMPEL SURABAYA
}

\author{
Desy Rahmadani ${ }^{1}$, Ali Nurdin ${ }^{2}$
}

1,2Universitas Islam Negeri Sunan Ampel Surabaya

11desyradani@gmail.com, ${ }^{2}$ ali.nurdin@uinsby.ac.id

\begin{tabular}{l}
\hline \hline Article Info \\
\hline Article history: \\
Received 21 Januari 2021 \\
Accepted 25 Februari 2021 \\
Published 1 April 2021
\end{tabular}

Keyword:

Komunikasi Pembelajaran, Materi Kuliah, Kelas Online

\begin{abstract}
This study discusses the effectiveness of online learning communication on the understanding of lecture material for UIN Sunan Ampel Surabaya students. This research method uses a quantitative approach with the type of correlational research. The data was collected using a questionnaire technique through the google form application, the sampling technique was carried out using a random sample technique, and analyzed using the Chi Square statistical formula and the Correlation Coefficient. The results showed that the calculation of the data using the Chi Square formula with the suitability of the table $0.05 \%$ resulted in $x 2$ arithmetic > x2 table (60.69 > 3.84), so Ha was accepted while Ho was rejected. It can be concluded that there is an effectiveness of online learning communication on the understanding of lecture material for UIN Sunan Ampel Surabaya students. Then, to measure the level of effectiveness, the researcher used the correlation coefficient formula and obtained a value of 0.134 with a very low category.

Penelitian ini membahas tentang efektifitas komunikasi pembelajaran daring terhadap pemahaman materi kuliah mahasiswa UIN Sunan Ampel Surabaya. Metode penelitian menggunakan pendekatan kuantitatif dengan jenis penelitian korelasional. Pengumpulan data dilakukan dengan teknik angket melalui aplikasi google formulir, teknik penentuan sampel dilakukan dengan teknik sampel acak, dan dianalisis dengan rumus statistik Chi Kwadrat dan Koefisien Korelasi. Hasil penelitian menunjukkan bahwa dari perhitungan data yang menggunakan rumus Chi Kwadrat dengan kesesuaian tabel 0,05\% menghasilkan $x^{2}$ hitung $>x^{2}$ tabel $(60,69>3,84)$, sehingga Ha diterima sedangkan Ho ditolak. Dapat disimpulkan bahwa terdapat efektivitas komunikasi pembelajaran daring terhadap pemahaman materi kuliah mahasiswa UIN Sunan Ampel Surabaya. Kemudian, untuk mengukur tingkat efektivitas, peneliti menggunakan rumus koefisiensi korelasi dan diperoleh nilai sebesar 0,134 dengan kategori sangat rendah.
\end{abstract}

Copyright (C) 2021 Jurnal Ilmu Komunikasi

\section{Editorial Office:}

Program Studi Ilmu Komunikasi, Fakultas Dakwah dan Komunikasi, UIN Sunan Ampel Surabaya. Jl. Ahmad Yani 117 Surabaya, Jawa Timur, Indonesia.

Email: jurnalilkom@uinsby.ac.id 


\section{Pendahuluan}

Dunia saat ini sedang diguncang virus menular mematikan, yaitu coronavirus disease 2019, lebih dikenal dengan Covid-19 yang merupakan penyakit menular disebabkan oleh SARSCoV-2 salah satu jenis.virus corona. Di Indonesia, penyebaran virus corona begitu dahsyat menyerang orang tanpa melihat jenis kelamin, usia, status sosial, dan pekerjaan, dan telah menginfeksi lebih dari 5.000 orang ${ }^{1}$. Realitas ini mengharuskan adanya kerjasama antara masyarakat, pemerintah, dan instansi terkait untuk melakukan pencegahan penyebaran virus corona agar tidak terjadi peningkatan dalam penyebarannya ${ }^{2}$. Tindakan pencegahan melalui penetapan social distancing/physical distancing oleh pemerintah menyebabkan banyaknya aktivitas yang terhambat termasuk bidang pendidikan. Pemerintah melalui kementerian pendidikan dan kebudayaan mengeluarkan surat edaran tentang penyelenggaraan proses pembelajaran di perguruan tinggi untuk dialihkan secara daring ${ }^{3}$.

Komunikasi pembelajaran dalam masa pandemi COVID-19 mengalami perubahan,

1 Sofia Al Farizi and Bagus Nuari Harmawan, "Data Transparency and Information Sharing: Coronavirus Prevention Problems in Indonesia," JAKI, Jurnal Administrasi Kesehatan Indonesia 8, no. 2 (June 2020): 35, https://doi.org/10.20473/jaki.v8i2.2020.35-50.

${ }^{2}$ Sukma Sindi et al., "Analisis Algoritma KMedoids Clustering Dalam Pengelompokan Penyebaran Covid-19 Di Indonesia," JurTI (Jurnal Teknologi Informasi) 4, no. 1 (Juni 2020): 166, https://dx.doi.org/10.36294/jurti.v4i1.1296

3 Ali Sadikin dan Afreni Hamidah, "Pembelajaran Daring Di Tengah Wabah Covid-19: (Online Learning in the Middle of the Covid-19 Pandemic)," Biodik 6, no. 2 (June 2020): 214, https://doi.org/10.22437/bio.v6i2.9759. dari tatap muka langsung ke tatap muka virtual. Efektivitas komunikasi pembelajaran secara tatap muka langsung memiliki sentuhan komunikasi empati yang tidak ditemukan dalam komunikasi pembelajaran berbasis daring untuk mencegah terjadinya penyebaran virus corona. Komunikasi pembelajaran daring dilakukan secara virtual didukung jaringan internet dengan perangkat teknologi komputer berbasis internet, seperti personal computer, laptop, smartphone berbasis android, dan sebagainya yang terhubungkan dengan jaringan internet ${ }^{4}$. Selain itu, dosen dan mahasiswa juga memerlukan media sebagai penghubung satu dengan yang lainnya, seperti: WhatsApp Group, Line Group, Google Classroom, Zoom, dan lainnya ${ }^{5}$.

Banyaknya media pembelajaran yang berkembang dengan berbagai macam fitur yang tersedia, tidak dapat menghapuskan kendala yang dimiliki oleh para mahasiswa selama proses perkuliahan ${ }^{6}$. Sedikit kendala kuliah daring berbasis internet karena tidak semua daerah memiliki jaringan internet yang bagus, terutama bagi yang tinggal di daerah pedesaan. Ketika jaringan internet terhambat maka penyampaian pesan dalam

4 Sadikin dan Hamidah, "Pembelajaran Daring," 216.

${ }^{5}$ Shen Shadiqien, "Efektivitas Komunikasi Virtual Pembelajaran Daring Dalam Masa PSBB (Studi Kasus Pembelajaran Jarak Jauh Produktif Siswa SMK Negeri 2 Banjarmasin)," Jurnal Mutakallimin, Jurnal Ilmu Komunikasi 3, no. 1 (Mei 2020): 11, https://ojs.uniskabjm.ac.id/index.php/mutakallimin/article/view/357 3.

6 Agusmanto JB Hutauruk, "Kendala Pembelajaran Daring Selama Masa Pandemi di Kalangan Mahasiswa Pendidikan Matematika: Kajian Kualiatatif Deskriptif," SEPREN 2, no. 1 (September 2020): 45, https://doi.org/10.36655/sepren.v2i1. 
proses belajar mengajar tidak dapat tersampaikan dengan sempurna.

Berbagai hambatan yang ditemukan selama proses komunikasi pembelajaran daring tentunya tidak boleh mengurangi tingkat pemahamanan mahasiswa dalam menyerap transformasi pengetahuan yang diberikan oleh dosen ${ }^{7}$. Fenomena yang terjadi pada mahasiswa UIN Sunan Ampel selama menyelenggrakan program kuliah jarak jauh berbasis internet pada semester gasal tahun 2020-2021 menunjukkan bahwa banyak mahasiswa UIN Sunan Ampel yang mengeluh selama proses komunikasi pembelajaran daring dilakukan. Hal ini disebabkan oleh pertama, sulitnya koneksi internet yang didapat, kedua, mahalnya biaya internet, ketiga, kesulitan dalam mengakses media pembelajaran. Semangat dalam mengikuti perkuliahan semakin menurun, banyak materi perkuliahan yang tidak dimengerti, sulitnya menangkap pesan dan informasi yang diberikan oleh dosen, sehingga berakibat salah dalam menafsirkan makna yang dimaksudkan oleh dosen, dan menurunnya nilai kuliah

\section{Kajian Pustaka}

\section{Komunikasi Pembelajaran Daring}

Komunikasi memiliki peran penting dalam proses pembelajaran yakni mengelola proses penyampaian dan penerimaan materi belajar. Interaksi interpersonal yang efektif dan harmonis

7 Aan Widiyono, "Efektifitas Perkuliahan Daring (Online) Pada Mahasiswa Pgsd Di Saat Pandemi Covid 19," Jurnal Pendidikan 8, no. 2 (Juli 2020): 170,

https://doi.org/10.36232/pendidikan.v8i2.458.

8 Ali Nurdin, Teori Komunikasi Interpersonal : Disertai Contoh Fenomena Praktis (Jakarta : Kencana Prenadamedia Group, 2020), 20. antara dosen dengan mahasiswa dalam proses perkuliahan dapat berperan dalam meningkatkan pengetahuan dan pemahaman. Interaksi yang dibangun antara siswa dan guru harus dibangun secara berkelanjutan, tidak hanya di ruang belajar, namun juga di luar ruang belajar. Pesan yang disampaikan secara personal (guru) harus dilakukan berkelanjutan mulai dari pengiriman atau penyampaian pesan, penerimaan, dan pemahamanan. Komunikasi pembelajaran harus berjalan secara interaktif dan memberi ruang kesepakatan bersama dalam memahami pesan yang disampaikan, diterima, dan dipahami secara bersama ${ }^{8}$.

Komunikasi pembelajaran dapat efektif jika dilakukan dengan memenuhi elemen daya tarik, pemahaman, penerimaan, keterlibatan, dan keyakinan ${ }^{9}$. Lima elemen ini dapat dilakukan ketika penyampaian pesan dilakukan secara tatap muka langsung. Namun, ketika masa pandemi COVID-19 yang menerapkan pembelajaran jarak jauh berbasis internet, lima elemen ini dalam penerapannya menemui hambatan karena ruang gerak komunikator (guru) dan komunikasn (siswa) yang terbatas dalam pembelajaran daring. Pembelajaran daring yaitu proses transformasi pengetahuan dalam pembelajaran yang dilakukan dengan sistem penyebaran materi ajar secara terbuka dengan media pembelajaran

9 Basori Basori, "Efektifitas Komunikasi Pembelajaran Online Dengan Menggunakan Media E-Learning Pada Perkuliahan Body Otomotif," Jurnal Ilmiah Pendidikan Teknik Dan Kejuruan 7, no. 2 (July 2014): 39,

DOI:10.20961/jiptek.v7i2.12722. 
berbasis jaringan internet yang kuat untuk melakukan interaksi pada saat proses pembelajaran berlangsung ${ }^{10}$. Kelancaran pembelajaran daring ditunjang dengan adanya jaringan internet yang kuat, karena tanpa adanya jaringan internet yang kuat, maka pengajar dan peserta didik tidak dapat melangsungkan kegiatan belajar mengajar dengan baik ${ }^{11}$.

Sistem pembelajaran berbasis internet memerlukan dukungan dengan menggunakan aplikasi media yang dapat membantu mempermudah dalam proses transfer keilmuan ketika mengajar ${ }^{12}$. Aplikasi media yang dapat membantu kegiatan pembelajaran berbasis internet atau online dapat berupa aplikasi seperti; google classroom, zoom, whatsapp, quizizz, dan lainnya.

Adanya virus corona mengharuskan seluruh jenjang pendidikan melanjutkan kegiatan akademik secara online, termasuk mahasiswa Internasional Ghana di China. Penelitian ini menjelaskan bahwa implementasi pembelajaran online adalah ide yang sangat bagus karena mayoritas sampel mendukung inisiatif kegiatan ini.

10 Novita Arnesti dan Abdul Hamid, "Penggunaan Media Pembelajaran Online-Offline Dan Komunikasi Interpersonal Terhadap Hasil Belajar Bahasa Inggris," Jurnal Teknologi Informasi \& Komunikasi Dalam Pendidikan 2, no. 1 (Juni 2015): 88, https://doi.org/10.24114/jtikp.v2i1.3284.

11 Hakiman, "Pembelajaran Daring," diakases 27 Desember, 2020, https://iainsurakarta.ac.id/\%EF\%BB\%BFpembelajarandaring.

12 Oktafia Ika Handarini dan Siti Sri Wulandari, "Pembelajaran Daring Sebagai Upaya Study From Home (SFH) Selama Pandemi Covid 19," Jurnal Pendidikan Administrasi Perkantoran (JPAP) 8, no. 3 (Desember 2020): 498, https://journal.unesa.ac.id/index.php/jpap/article/vi ew/8503.
Namun, muncul keluahn tentang mahalnya biaya untuk berpartisipasi dalam pembelajaran online sehingga mahasiswa menghabiskan banyak uang untuk membeli data internet, terlebih koneksi internet yang lambat sehingga komunikasi saat pembelajran terganggu ${ }^{13}$. Survey tentang efektivitas belajar online selama pandemi dan pembelajaran jarak jauh dilakukan dengan objek penelitian para mahasiswa dari berbagai universitas yang berada di Polandia. Survey dilakukan secara online dan menjelaskan bahwa pembelajaran jarak jauh dapat memenuhi tugas meskipun mahasiswa lebih memilih untuk belajar di univeritas daripada di rumah $^{14}$.

Di Indonesia, pembelajaran daring pada masa pandemi COVID-19 memiliki kendala jaringan internet, dan mahasiswa lebih memilih untuk belajar tatap muka. Hal ini dilakukan dengan alasan bahwa pembelajaran tatap muka secara langsung memberikan ruang interaksi antara dosen dan mahasiswa yang lebih bebas dan rilek dalam memahami materi belajar yang disampaikan oleh dosen ${ }^{15}$. Sebaliknya, ada

13 John Demuyakor, "Coronavirus (COVID19) and Online Learning in Higher Institutions of Education: A Survey of the Perceptions of Ghanaian International Students in China," Online Journal of Communication and Media Technologies 10, no. 3 (May 2020): 2, https://doi.org/10.29333/ojcmt/8286.

${ }^{14}$ Kinga Olszewska, "The Effectiveness of Online Learning in the Era of the SARS-CoV-2 Pandemic on the Example of Students of Polish Universities," World Scientific News 148 (August 2020): 108

http://www.worldscientificnews.com/wpcontent/uploads/2020/08/WSN-148-2020-108121.pdf.

15 Lizha Dzalila, Annisa Ananda, dan Saifuddin Zuhri, "Pengaruh Pembelajaran Daring Pada Masa Pandemi COVID-19 terhadap Tingkat 
penelitian tentang efektivitas pembelajaran dengan menggunakan media google classroom dinyatakan efektif ${ }^{16}$. Begitu juga hasil penelitian ini, komunikasi pembelajaran daring menemukan tingkat efektivitas, namun dalam kategori efektivitas sangat rendah.

\section{Pemahaman Materi Kuliah}

Pemahaman merupakan hasil dari belajar ${ }^{17}$. Pemahaman adalah kompetensi yang dimiliki seseorang untuk dapat mengerti dan memahami tentang apa yang ketahui melalui daya pendengaran, penglihatan, dan ingatan ${ }^{18}$. Jadi, seorang siswa atau mahasiswa dapat dikatakan memiliki kemampuan memahami jika siswa atau mahasiswa tersebut memiliki kemampuan untuk mengutarakan kembali apa yang diketahuinya secara runtut dan sistematis sesuai dengan bahasa dan pola pikirnya sendiri. Bloom menyebutkan bahwa kemampuan pemahaman dibagi berdasarkan tingkat kepekaan dan derajat menjadi tiga; pertama, kemampuan menerjemahkan, yaitu penguasaan pemahaman tentang makna yang terkandung dalam konsep tertentu. Kedua,

Pemahaman Beajar Mahasiswa," JURNAL SIGNAL 8, no. 2 (Desember 2020): 203,

http://dx.doi.org/10.33603/signal.v8i2.3518.

16 Wanda Hanifah dan K. Y. S. Putri, "Efektivitas Komunikasi Google Classroom Sebagai Media Pembelajaran Jarak Jauh Pada Mahasiswa Ilmu Komunikai Universitas Negeri Jakarta Angkatan 2018," MEDIALOG: Jurnal Ilmu Komunikasi 3, no. 2 (Agustus 2020): 24,

https://doi.org/10.35326/medialog.v3i2.639

17 Nana Sudjana, Penilaian Hasil Proses

Belajar Mengajar (Bandung: PT. Remaja Rosdakarya, 1995), 24.

18 Anas Sudijono, Pengantar Evaluasi

Pendidikan (Jakarta: Rajawali Pers, 2011), 50. kemampuan menafsirkan, yaitu kemampuan membuat interpretasi makna yang terkandung dalam konsep tertentu. Ketiga, kemampuan mengeksplorasi, yaitu kemampuan seseorang dalam menguraikan makna tersembunyi dari teks yang tampak $^{19}$.

Materi perkuliahan adalah bahan ajar atau materi yang disampaikan oleh guru atau dosen kepada siswa atau mahasiswa dengan tujuan transfer pengetahuan agar peserta didik memiliki kemampuan untuk mengetahui, memahami, dan menguasai materi ajar sesuai dengan kompetensi yang telah ditetapkan ${ }^{20}$. Materi pembelajaran merupakan bahan yang penting dan harus dikuasai untuk memenuhi standar kompetensi yang sudah ditetapkan, dan diperlukan untuk proses pembentukan sikap, keterampilan, dan pengetahuan ${ }^{21}$.

\section{Teori S-O-R dan Teori Determinasi Teknologi dalam Komunikasi Pembelajaran Daring}

Teori S-O-R menjelaskan bahwa dalam komunikasi terjadi proses aksireaksi ${ }^{22}$. Dalam teori S-O-R menjelaskan proses aksi-reaksi dengan terjadinya

19 Wowo Sunaryo Kuswana, Taksonomi Kognitif (Bandung: PT Remaja Rosdakarya, 2012), 44.

20 Kasrul Anwar and Hendra Harmi, Perencanaan Sistem Pembelajaran Kurikulum Tingkat Satuan Pendidikan (KTSP) (Bandung: CV Alfabeta, 2011), 101-102.

21 Mardia Hayati, Desain Pembelajaran: Berbasis Karakter (Pekanbaru: Al-Mujtahadah Press, 2012), 61.

${ }^{22}$ Veby Zilfania Rizal and Evawani Elysa Lubis, "Social Media Marketing Twitter Dan Brand Image Restoran Burger," Jurnal Ilmu Komunikasi 5, no. 1 (Maret 2014): 106, https://jom.unri.ac.id/index.php/JOMFSIP/article/v iew/2419. 
peristiwa dialektif antara unsur pesan, komunikan, dan efek. Unsur pesan diidentifikasi sebagai stimulus (S), komunikan diidentifikasi sebagai unsur organism $(O)$, dan efek diidentifikasi sebagai response $(R)$. Dialektika antara ketiga unsur ini (S-O-R) menghasilkan proses komunikasi yang menekankan adanya perubahan sikap dalam mempertanyakan aspek 'bagaimana' (how) daripada aspek 'apa'(what) dan 'mengapa' (why). Stimulus yang disampaikan kepada komunikan terdapat kemungkinan untuk ditolak ataupun diterima. Aspek perhatian, pengertian, dan perimaan adalah faktor penentu dalam dialektika komunikasi yang sedang berlangsung ${ }^{23}$.

Proses pembelajaran daring dalam penelitian ini merupakan aksi yang memiliki reaksi berupa pemahaman materi kuliah pada mahasiswa. Unsur utamanya, yaitu: pesan atau stimulus berupa materi yang disampaikan oleh dosen melalui media komunikasi pembelajaran. Komunikan atau organism merupakan para mahasiswa yang sedang mengikuti pembelajaran daring, dan efek atau response berupa pemahaman materi kuliah mahasiswa setelah mengikuti pembelajaran daring.

McLuhan dalam teori determinasi teknologi mengemukakan bahwa aspek

23 Christopher Christopher, "Sikap Masyarakat Surabaya Dalam Menonton Video Klip Psy-Gangnam Style Di Youtube," Thesis (Petra Christian University: 2013), 188.

24 Asep Saefudin, "Perkembangan Teknologi Komunikasi: Perspektif Komunikasi Peradaban," Mediator: Jurnal Komunikasi 9, no. 2 (December 2008): 384,

DOI:10.29313/mediator.v9i2.1113.

25 Ajeng Iva Dwi Febriana, "Determinasi Teknologi Komunikasi Dan Tutupnya Media Sosial utama yang menentukan atau mempengaruhi lingkungan sekitarnya adalah media ${ }^{24}$. Teori determinasi menjelaskan bahwa tindakan individu dalam masyarakat, apa yang dipikirkan, dan apa yang dirasakan sangat dipengaruhi oleh teknologi media ${ }^{25}$.

\section{Metode Penelitian}

Pendekatan penelitian ini adalah penelitian kuantitatif dengan menggunakan jenis penelitian korelasionnal (correlational research) yaitu menjelaskan tentang tingkat hubungan atau korelasi antar variabel yang digunakan berdasarkan indikator-indikator yang telah ditentukan ${ }^{26}$. Kekuatan korelasi atau tingkat hubungan antar variabel, yaitu variabel independent/bebas (X) yakni komunikasi pembelajaran daring, sementara dependen/terikat (Y) pemahaman materi perkuliahan.

Populasi adalah sekumpulan sasaran penelitian yang ditentukan, tinggal di wilayah geografis tertentu, memiliki karakteristik tertentu, dapat homogen maupun heterogen, dan dapat digunakan untuk menggeneralasisasi hasil kesimpulan dari suatu penelitian ${ }^{27}$.

Populasi penelitian ini adalah seluruh mahasiswa aktif tingkat sarjana (S1) UIN Sunan Ampel Surabaya pada semester

Path," LONTAR: Jurnal Ilmu Komunikasi 6, no. 2 (Juli 2018): 86, https://doi.org/10.30656/lontar.v6i2.948.

26 Sumadi Suryabrata, Metodologi Penelitian (Jakarta: Raja Grafindo Persada, 1998), 24.

27 Sandu Siyoto and Ali Sodik, Dasar Metodologi Penelitian (Yogyakarta: Literasi Media Publishing, 2015), 80. 
gasal tahun 2020-2021 yang berjumlah 19.418 mahasiswa ${ }^{28}$. Dari jumlah populasi di atas, maka ditentukan jumlah sampelnya, yaitu jumlah yang representatif dari populasi dengan karakteristik yang telah ditentukan dari populasi ${ }^{29}$. Sampel yang ditentukan memiliki presisi tingkat kepercayaan 95\% dengan menggunakan rumus Yamane sebagai berikut ${ }^{30}$ :

$$
\begin{aligned}
& n=\frac{N}{N(d)^{2}+1} \\
& n=\frac{19.418}{19.418(5 \%)^{2}+1} \\
& n=391,92
\end{aligned}
$$

Hasil perhitungan di atas kemudian jumlah sampel dibulatkan menjadi 392 mahasiswa aktif tingkat sarjana (S1) UIN Sunan Ampel Surabaya pada semester gasal tahun 2020-2021 yang terdiri dari sembilan (9) fakultas. Sampel atau responden ditentukan secara acak (random sampling) yaitu setiap responden memiliki peluang yang sama untuk terpilih sebagai responden.

Indikator penelitian ini ada dua; (a) indikator variabel komunikasi pembelajaran daring yang terdiri dari; kekuatan jaringan internet, jenis media yang digunakan, dan fitur yang tersedia. (b) indikator variabel pemahaman materi kuliah terdiri dari; mampu memahami pesan utama materi, mampu memahami makna tersirat materi, dan mampu menjelaskan materi kembali. Dari indikator ini kemudian dibuat sembilan (9) pertanyaan dari masing-masing variabel,

28 "Data Mahasiswa," diakses 24 November, 2020 ,

https://forlap.ristekdikti.go.id/perguruantinggi/sear ch. sehingga total ada 18 pertanyaan. Nilai score dalam setiap pertanyaan atas jawaban ya adalah 1 , dan jawaban tidak memiliki nilai 2.

Peneliti melakukan pengumpulan data melalui angket, data yang terkumpul kemudian ditabulasi, dikoding, dan dianalisis untuk menguji hipotesis yang ditentukan yaitu hipotesis kerja (Ha) dan hipotesis nihil (Ho). Pengujian hipotesis dilakukan dengan menggunakan langkahlangkah sebagai berikut:

a. Uji hipotesis efektivitas komunikasi pembelajaran daring terhadap pemahaman materi kuliah mahasiswa UIN Sunan Ampel Surabaya. Uji hipotesis dilakukan dengan rumus statistika untuk mengetahui apakah hipotesis kerja diterima atau ditolak. Langkah yang dilakukan adalah mencari rata-rata (mean) dengan rumusan sebagai berikut:

$$
M=\frac{F}{N}
$$

b. Untuk mengetahui efektivitas komunikasi pembelajaran daring terhadap mahasiswa UIN Sunan Ampel Surabaya, peneliti menggunakan rumus chi kuatdrat $\left(\mathrm{x}^{2}\right)$ sebagai berikut: $x^{2}=\sum \frac{(O-E)^{2}}{E}$

c. Untuk mengetahui sejauhmana tingkat pemahaman materi mahasiswa UIN Sunan Ampel Surabaya, peneliti menggunakan rumus Koefiensi Kontingengensi (KK) sebagai berikut:

${ }^{29}$ Sugiyono, Motode Penelitian Kuantitatif Dan R\&D (Bandung: Alfabeta, 2010), 117.

${ }^{30}$ Rachmat Kriyantono, Teknik Praktis Riset Komunikasi (Jakarta: Kencana, 2006), 164. 


$$
C=\sqrt{\frac{x^{2}}{x^{2}+N}}
$$

\section{Hasil dan Pembahasan}

\section{Sekilas UIN Sunan Ampel Surabaya}

Universitas Islam Negeri Sunan Ampel Surabaya merupakan salah satu universitas Islam yang memiliki paradigma pengembangan integrasi twin towers yaitu landasan nilai-nilai pendidikan yang mengintegrasikan paradigma ke-Islaman dengan keilmuan umum. Universitas Islam Negeri Sunan Ampel berdiri sejak tahun 1961 yang dulunya bernama IAIN Sunan Ampel dan merupakan perguruan tinggi Islam negeri yang ada di Surabaya. Universitas Islam Negeri Sunan Ampel Surabaya memiliki 42 program studi keagamaan dan umum yang menyebar di 9 fakultas.

\section{Uji Hipotesis}

Pengujian hipotesis dalam penelitian ini dilakukan dengan mengelompokkan nilai (score) yang telah didapat dari jawaban responden melalui angket dengan mencari rata-rata (Mean) dengan rumus perhitungan sebagai berikut:

Komunikasi Pembelajaran Daring (Variavel X)

$$
\begin{aligned}
& M=\frac{F}{N} \\
& M=\frac{4550}{392} \\
& M=11,6
\end{aligned}
$$

Nilai rata-rata yang dihasilkan dari penghitungan variabel komunikasi pembelajaran daring (variabel $\mathrm{X}$ ) adalah 11,6 yang kemudian nilai yang >11,6 dikategorikan sebagai nilai (+) atau tinggi, sedangkan nilai yang <11,6 dikategorikan sebagai nilai (-) atau rendah.

Pemahaman Materi Kuliah (Variabel Y)

$$
\begin{aligned}
& M=\frac{F}{N} \\
& M=\frac{4185}{392} \\
& M=10,6
\end{aligned}
$$

Nilai rata-rata yang dihasilkan dari penghitungan variabel pemahaman materi kuliah (variabel Y) adalah 10,6 yang kemudian nilai yang >10,6 dikategorikan sebagai nilai (+) atau tinggi, sedangkan nilai yang $<10,6$ dikategorikan sebagai nilai (-) atau rendah.

Hasil tabulasi masing-masing variabel diperoleh jumlah dari kategori variabel $\mathrm{X}$ dan variabel $\mathrm{Y}$ kemudian dianalisis menggunakan rumus analisis statistik yaitu Chi Kuadrat/ Chi Square untuk menguji efektivitas komunikasi pembelajaran daring terhadap pemahaman materi kuliah mahasiswa.

Tabel 1:

Kategori data penelitian efektivitas pembeljaaran daring terhadap pemahaman materi kuliah mahasiswa

\begin{tabular}{|c|c|c|c|}
\hline & + & - & Total \\
\hline+ & 96 & 81 & 143 \\
\hline- & 47 & 168 & 249 \\
\hline Total & 177 & 215 & 392 \\
\hline
\end{tabular}


Dari tabel di atas diketahui bahwa :

$O_{1}=96$

$\mathrm{O}_{2}=81$

$\mathrm{O}_{3}=47$

$\mathrm{O}_{4}=168$

Langkah selanjutnya yaitu mencari E (frekuensi yang diharapkan), sebagai berikut:

$E=\sum \frac{\text { Baris } x \text { Kolom }}{N}$

Dari rumus tersebut diperoleh:

$E 1=\sum \frac{177 \times 143}{392}=64,57$

$E 2=\sum \frac{215 X 143}{392}=78,43$

$E 3=\sum \frac{177 \times 249}{392}=112,43$

$E 4=\sum \frac{215 \times 249}{392}=136,57$

Setelah $O$ telah diketahui, lalu dimasukkan kedalam rumus Chi Kwadrat seperti berikut:

$\mathrm{x}^{2}=\sum \frac{(O-E)^{2}}{E}$

$\mathrm{x}^{2}=\frac{(O 1-\mathrm{E} 1)^{2}}{E 1}+\frac{(O 2-\mathrm{E} 2)^{2}}{E 2}+\frac{(O 3-\mathrm{E} 3)^{2}}{E 3}+$ $\frac{(04-\mathrm{E} 4)^{2}}{E 4}$

$x^{2}=\frac{(96-64,57)^{2}}{64,57}+\frac{(81-78,43)^{2}}{78,43}+\frac{(47-112,43)^{2}}{112,43}$ $+\frac{(168-136,57)^{2}}{136,57}$

$\mathrm{x}^{2}=15,3+0,08+38,08+7,23$

$x^{2}=60,69$

Tabel 2:

Perhitungan Chi Kwadrat

\begin{tabular}{|c|c|c|c|c|c|c|}
\hline $\mathrm{X}$ & $\mathrm{Y}$ & $O$ & $\mathrm{E}$ & $(O-\mathrm{E})$ & $(O-\mathrm{E})^{2}$ & $\frac{(O-E)^{2}}{E}$ \\
\hline+ & + & 96 & 64,57 & 31,43 & 987,84 & 15,3 \\
\hline+ & - & 81 & 78,43 & 2,57 & 6,6 & 0,08 \\
\hline
\end{tabular}

\begin{tabular}{|c|c|c|c|c|c|c|}
\hline- & + & 47 & 112,43 & $-65,43$ & $4.281,08$ & 38,08 \\
\hline- & - & 168 & 136,57 & 31,43 & 987,84 & 7,23 \\
\hline Total & 392 & 392 & 0 & $6.263,36$ & 60,69 \\
\hline
\end{tabular}

Sesuai dengan rumus perhitungan data di atas maka disimpulkan bahwa nilai $x^{2}$ adalah 60,69. Kemudian untuk mengetahui keabsahan hipotesis dapat menggunakan rumus perhitungan sebagai berikut

$$
\begin{aligned}
\mathrm{db} & =(\mathrm{b}-1)(\mathrm{k}-1) \\
& =(2-1)(2-1) \\
& =(1)(1) \\
& =1
\end{aligned}
$$

Keterangan:

$\mathrm{db}=$ keabsahan data

$\mathrm{b}=$ baris

$\mathrm{k}=$ kolom

Sesuai dengan penghitungan rumus dan penjelasan di atas dapat diketahui bahwa dengan taraf tingkat signifikansi 5\% dan nilai $\mathrm{db} 1$, ditemukan nilai $\mathrm{x}^{2}$ tabel adalah 3,841. Jika nilai Chi Kwadrat hitung lebih besar daripada Chi Kwadrat tabel, maka hipotesis kerja (Ha) diterima, jika sebaliknya, jika nilai Chi Kwadrat hitung lebih kecil dari Chi Kwadrat tabel maka hipotesis nihil (Ho) ditolak.

Hasil tabulasi data tersebut diketahui bahwa hasil penghitungan dari rumus Chi Kuadrat hitung lebih besar daripada Chi Kuadrat tabel. Jika dituliskan dalam bentuk angka ialah $(60,69>3,84) \quad$ Sebagai konsekuensinya hipotesis kerja diterima dan hipotesis nihil ditolak ( $\mathrm{Ha}>\mathrm{Ho}$ ). 
Tingkat efektivitas komunikasi pembelajaran daring terhadap pemahaman materi perkuliahan menggunakan rumus koefiensi kontingengensi (KK) :

$$
\begin{gathered}
C=\sqrt{\frac{x^{2}}{N+x^{2}}} \\
C=\sqrt{\frac{60,69}{392+60,69}} \\
C=\sqrt{\frac{60,69}{452,69}} \\
C=0,134
\end{gathered}
$$

Berdasarkan perhitungan statistika dapat diketahui bahwa koefisien kontingensinya sebesar 0,134, tingkat hubungan nilai tersebut dapat dibaca "sangat rendah", sebagaimana tabel koefisien korelasi :

Tabel 3 :

Tabel Koefisiensi Korelasi

\begin{tabular}{|c|c|}
\hline Koefisien Korelasi & Tingkat Hubungan \\
\hline $0,00-0,199$ & Sangat rendah \\
\hline $0,20-0,399$ & Rendah \\
\hline $0,40-0,599$ & Sedang \\
\hline $0,60-0,799$ & Kuat \\
\hline $0,80-1,000$ & Sangat kuat \\
\hline
\end{tabular}

Data pendukung terkait pertanyaan di dalam angket juga menunjukan banyak mahasiswa yang kurang paham terkait materi perkuliahan selama mengikuti pembelajaran daring. Berikut diagramnya:

\section{Diagram 1:}

Pemahaman Materi Kuliah Mahasiswa Dalam Pembelajaran Daring

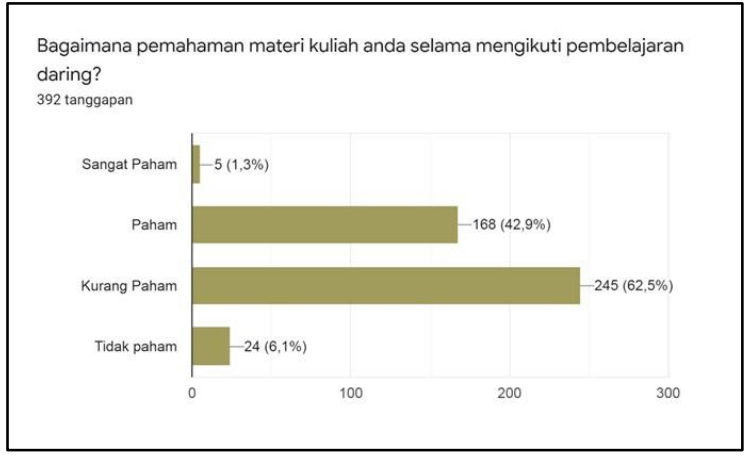

Pada diagram di atas, mahasiswa dapat memilih opsi lebih dari satu dan hasil yang didapat adalah banyak mahasiswa yang memilih jawaban "kurang paham" $(62,5 \%)$ terhadap pemahaman materi selama mengikuti pembelajaran daring, namun masih ada juga mahasiswa yang menjawab "paham" dengan prosentase $1,3 \%$.

\section{Perspektif Teori S-O-R, Teori Determinasi Teknologi, dan Nilai Ke- Islaman}

Kajian perspektif teori S-O-R, materi yang diberikan dosen dapat memberikan efek berupa pemahaman materi kuliah bagi mahasiswa. Namun efek itu dapat berupa hal yang positif ataupun negatif. Efek positif ditunjukkan bahwa ada sebagian kecil mahasiswa memiliki pemahaman tentang materi kuliah yang disampaikan melalui pembelajaran daring. Sebaliknya, efek negatif yang tidak diperhitungkan adalah sebagian besar mahasiswa tidak mampu memahami pesan atau materi kuliah yang disampaikan melalui pembelajaran daring. Ada beberapa faktor yang dapat mempengaruhi efektivitas pembelajaran daring, yaitu faktor pemilihan aplikasi media, tersedianya jaringan internet yang kuat secara timbal 
balik (dosen-mahasiswa), kejelasan pesan yang disampaikan, dan penerimaan pesan yang baik dari komunikan.

Menurut teori S-O-R, ketika materi disampaikan dengan tepat (stimulus) dan pemilihan media juga tepat sasaran, maka mahasiswa (organisme) dapat paham memahami isi materi (response). Sebaliknya, apabila materi yang disampaikan tidak tersampaikan dengan tepat karena adanya beberapa kendala, maka mahasiswa mendapatkan efek berupa ketidakpahaman terkait materi kuliah yang telah disampaikan oleh dosen.

Teori determinasi teknologi yang digagas oleh McLuhan menyebutkan bahwa media merupakan hal utama yang menentukan atau mempengaruhi hal yang lainnya. Pada penelitian ini, media komunikasi atau media pembelajaran daring sangat berperan penting dalam mempengaruhi pemahaman materi kuliah pada mahasiswa. Masa pandemi COVID19 'memaksa' adanya penggunaan media pembelajaran berbasis daring. Kondisi ini semakin memperkuat determinasi penggunaan media dalam kehidupan bermasyarakat, khususnya dalam proses pembelajaran. Pelaksanaan pembelajaran daring yang menggunakan media komunikasi, dapat berjalan baik dengan adanya jaringan internet yang kuat. Sebaliknya, jika jaringan internet yang dimiliki dosen atau mahasiswa terganggu, maka akan berpengaruh pada penangkapan materi yang disampaikan dosen.

Dalam perspektif nilai ke-Islaman, Islam mewajibkan umatnya untuk terus belajar. Pada masa pandemi COVID-19 sekalipun kegiatan proses belajar mengajar harus tetap berjalan, maka Rektor UIN Sunan Ampel mengeluarkan kebijakan dengan menghimbau untuk melaksanakan kegiatan pembelajaran atau perkuliahan dengan sistem daring.

Dalam perspektif historis keislaman ditamsilkan dalam cerita Nabi Sulaiman, ketika Nabi Sulaiman As. ingin mneyampaikan sebuah pesan kepada Ratu Balqis, namun terkendala dengan jarak. Akhirnya, Nabi Sulaiman menggunakan burung hud-hud sebagai perantara penggirim surat agar pesan yang ingin disampaikan kepada Ratu Balqis dapat tersampaikan. Kisah ini tertuang pada ayat Al-Quran Surat An-Naml ayat 29-30;

Artinya:

"Dia (Balqis) berkata, "Wahai para pembesar! Sesungguhnya telah disampaikan kepadaku sebuah surat yang mulia"(29). Sesungguhnya (surat) itu dari Sulaiman yang isinya, "Dengan nama Allah Yang Maha Pengasih, Maha Penyayang (30)".

Kisah Nabi Sulaiman dengan Ratu Balqis di atas sebagai tamsil teknologi komunikasi yang canggih pada masa itu. Proses komunikasi dapat disikapi dengan menggunakan media sehingga komunikasi tetap berjalan efektif dalam situasi apapun termasuk di masa pandemi COVID-19.

Temuan model komunikasi pembelajaran daring yang menghasilkan efektivitas dalam penyampaian pesan sebagai berikut:

Temuan model komunikasi pembelajaran daring yang menghasilkan efektivitas dalam penyampaian pesan sebagai berikut: 
Skema 1:

Model Komunikasi Pembelajaran Daring Yang Efektif

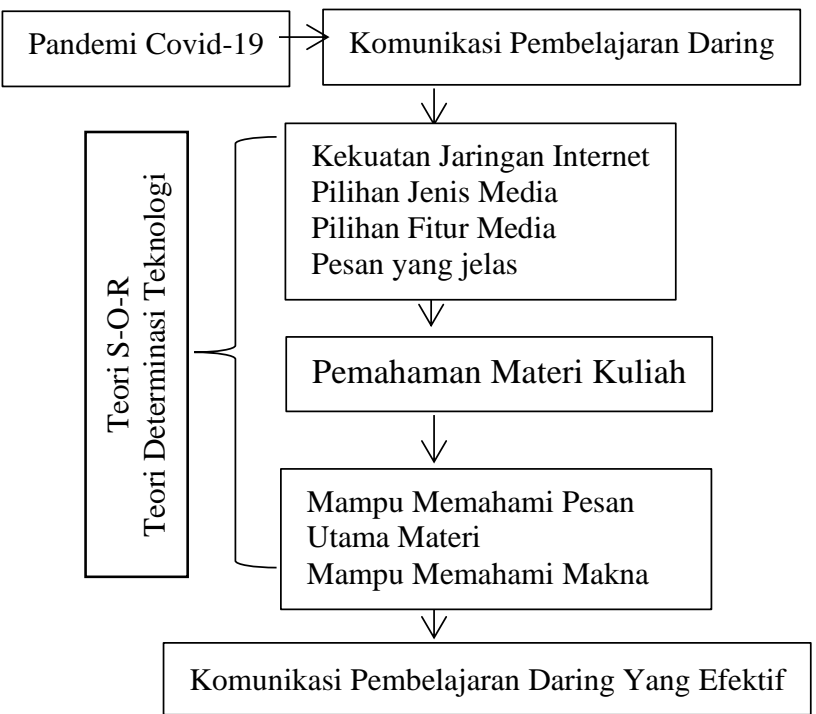

\section{Kesimpulan}

Hasil penelitian ini menyimpulkan bahwa komunikasi pembelajaran daring yang dilakukan di UIN Sunan Ampel Surabaya pada semester gasal tahun 20202021 memiliki efektivitas terhadap pemahaman materi kuliah mahasiswa. Uji statistik dilakukan dengan menggunakan rumus Chi Kwadrat dengan nilai hitung $\mathrm{x}^{2}$ adalah 60,69, sedangkan $\mathrm{x}^{2}$ tabel dengan $\mathrm{db}$ sebesar 1 dan tingkat kesalahan 5\% $(0,05)$ diperoleh nilai 3,81. Maka nilai hitung $\mathrm{x}^{2}$ lebih besar dari pada nilai table $\mathrm{x}^{2}(60,69>$ $3,81)$. Sehingga dapat disimpulkan bahwa hipotesis kerja yang menyatakan "ada efektivitas pembelajaran daring terhadap pemahaman materi kuliah mahasiswa" dapat diterima, dan hipotesis nihil dinyatakan ditolak. Hasil perhitungan tingkat koefisiensi korelasi dalam penelitian ini sebesar 0,134. Dengan demikian, tingkat efektifitas komunikasi pembelajaran daring terhadap pemahaman materi kuliah mahasiswa dinilai dalam kategori sangat rendah.

Penelitian ini direkomendasikan kepada semua pengguna media daring agar melakukan persiapan penguasaan teknologi komunikasi dan materi pesan yang akan disampaikan dengan baik agar mampu mendapatkan efektifitas komunikasi. Penelitian ini masih berpeluan besar untuk dilakukan penelitian lanjutan, karena masih banyak celah yang dapat dikaji dengan perspektif yang berbeda tentunya.

\section{Daftar Pustaka}

Anwar, Kasrul, dan Hendra Harmi. Perencanaan Sistem Pembelajaran Kurikulum Tingkat Satuan Pendidikan (KTSP). Bandung: CV Alfabeta, 2011.

Arnesti, Novita, dan Abdul Hamid. "Penggunaan Media Pembelajaran Online-Offline Dan Komunikasi Interpersonal Terhadap Hasil Belajar Bahasa Inggris.” Jurnal Teknologi Informasi \& Komunikasi Dalam Pendidikan 2, no. 1 (Juni 2015): 8599.

https://doi.org/10.24114/jtikp.v2i1.3 284.

Basori, Basori. "Efektifitas Komunikasi Pembelajaran Online Dengan Menggunakan Media E-Learning Pada Perkuliahan Body Otomotif." Jurnal Ilmiah Pendidikan Teknik Dan Kejuruan 7, no. 2 (July 2014): 39-45.

DOI:10.20961/jiptek.v7i2.12722.

Christopher, Christopher. "Sikap Masyarakat Surabaya Dalam Menonton Video Klip Psy-Gangnam 
Style Di Youtube." Thesis. Petra Christian University, 2013.

Demuyakor, John. "Coronavirus (COVID19) and Online Learning in Higher Institutions of Education: A Survey of the Perceptions of Ghanaian International Students in China." Online Journal of Communication and Media Technologies 10, no. 3 (May 2020): 1-9. https://doi.org/10.29333/ojcmt/8286.

Dzalila, Lizha, Annisa Ananda, dan Saifuddin Zuhri. "Pengaruh Pembelajaran Daring Pada Masa Pandemi COVID-19 Terhadap Tingkat Pemahaman Beajar Mahasiswa," JURNAL SIGNAL 8, no. 2 (Desember 2020): 203-214. http://dx.doi.org/10.33603/signal.v8i 2.3518 .

Farizi, Sofia Al., dan Bagus Nuari Harmawan. "Data Transparency and Information Sharing: Coronavirus Prevention Problems in Indonesia." JAKI, Jurnal Administrasi Kesehatan Indonesia 8, no. 2 (June 2020): $35-50$. https://doi.org/10.20473/jaki.v8i2.20 20.35-50.

Febriana, Ajeng Iva Dwi. "Determinasi Teknologi Komunikasi Dan Tutupnya Media Sosial Path." LONTAR, Jurnal Ilmu Komunikasi 6, no. 2 (Juli 2018): 10-17. https://doi.org/10.30656/lontar.v6i2. 948.

Forlap Dikti."Data Mahasiswa," diakses $24 \quad$ November, 2020. https://forlap.ristekdikti.go.id/pergur uantinggi/search.

Hakiman. "Pembelajaran Daring." diakases 27 Desember, 2020. https://iainsurakarta.ac.id/\%EF\%BB\%BFpemb elajaran-daring.
Handarini, Oktafia Ika, dan Siti Sri Wulandari. "Pembelajaran Daring Sebagai Upaya Study From Home (SFH) Selama Pandemi Covid 19." Jurnal Pendidikan Administrasi Perkantoran (JPAP) 8, no. 3 (Desember 2020): 496-503. https://journal.unesa.ac.id/index.php /jpap/article/view/8503.

Hanifah, Wanda, and K. Y. S. Putri. "Efektivitas Komunikasi Google Classroom Sebagai Media Pembelajaran Jarak Jauh Pada Mahasiswa Ilmu Komunikai Universitas Negeri Jakarta Angkatan 2018." MEDIALOG: Jurnal Ilmu Komunikasi 3, no. 2 (Agustus 2020): 24-35.

https://doi.org/10.35326/medialog.v 3i2.639.

Hayati, Mardia. Desain Pembelajaran: Berbasis Karakter. Pekanbaru: AlMujtahadah Press, 2012.

Hutauruk, Agusmanto JB. "Kendala Pembelajaran Daring Selama Masa Pandemi di Kalangan Mahasiswa Pendidikan Matematika: Kajian Kualiatatif Deskriptif." SEPREN 2, no. 1 (September 2020): 45-51. https://doi.org/10.36655/sepren.v2i1.

Kriyantono, Rachmat. Teknik Praktis Riset Komunikasi. Jakarta: Kencana, 2006.

Kuswana, Wowo Sunaryo. Taksonomi Kognitif. Bandung: PT Remaja Rosdakarya, 2012.

Nurdin, Ali. Teori Komunikasi Interpersonal: Disertai Contoh Fenomena Praktis. Jakarta: Kencana Prenadamedia Group, 2020.

Olszewska, Kinga. "The Effectiveness of Online Learning in the Era of the SARS-CoV-2 Pandemic on the Example of Students of Polish Universities." World Scientific News 148 (August 2020): 108-121. 
http://www.worldscientificnews.co

$\mathrm{m} / \mathrm{wp}-$

content/uploads/2020/08/WSN-1482020-108-121.pdf.

Rizal, Veby Zilfania, dan Evawani Elysa Lubis. "Social Media Marketing Twitter Dan Brand Image Restoran Burger.” Jurnal Ilmu Komunikasi 5, no. 1 (Maret 2014): 103-118. https://jom.unri.ac.id/index.php/JO MFSIP/article/view/2419.

Sadikin, Ali, dan Afreni Hamidah. "Pembelajaran Daring Di Tengah Wabah Covid-19: (Online Learning in the Middle of the Covid-19 Pandemic)," Biodik 6, no. 2 (June 2020): 214-24. https://doi.org/10.22437/bio.v6i2.97 59.

Saefudin, Asep. "Perkembangan Teknologi Komunikasi: Perspektif Komunikasi Peradaban." Mediator: Jurnal Komunikasi 9, no. 2 (December 2008): 383-392. DOI:10.29313/mediator.v9i2.1113.

Shadiqien, Shen. "Efektivitas Komunikasi Virtual Pembelajaran Daring Dalam Masa PSBB (Studi Kasus Pembelajaran Jarak Jauh Produktif Siswa SMK Negeri 2 Banjarmasin)." Jurnal Mutakallimin, Jurnal Ilmu Komunikasi 3, no. 1 (Mei 2020): 11$21 . \quad$ https://ojs.uniskabjm.ac.id/index.php/mutakallimin/ar ticle/view/3573.

Sindi, Sukma, et al. "Analisis Algoritma K-Medoids Clustering dalam Pengelompokan Penyebaran Covid19 Di Indonesia." JurTI (Jurnal Teknologi Informasi) 4, no. 1 (Juni 2020): 166 73. https://dx.doi.org/10.36294/jurti .v4i1.1296.

Siyoto, Sandu, dan Ali Sodik. Dasar Metodologi Penelitian. Yogyakarta: Literasi Media Publishing, 2015.
Sudijono, Anas. Pengantar Evaluasi Pendidikan. Jakarta: Rajawali Pers, 2011.

Sudjana, Nana. Penilaian Hasil Proses Belajar Mengajar. Bandung: PT. Remaja Rosdakarya, 1995.

Sugiyono. Motode Penelitian Kuantitatif Dan R\&D. Bandung: Alfabeta, 2010.

Suryabrata, Sumadi. Metodologi Penelitian. Jakarta: Raja Grafindo Persada, 1998.

Widiyono, Aan. "Efektifitas Perkuliahan Daring (Online) Pada Mahasiswa Pgsd Di Saat Pandemi Covid 19." Jurnal Pendidikan 8, no. 2 (Juli 2020): 169-177. https://doi.org/10.36232/pendidikan. v8i2.458. 